\title{
CRISIS AWARENESS OF THE MUNICIPAL DISTRICT RESIDENTS: IMPLICATION FOR CRISIS MANAGEMENT AT THE LOCAL GOVERNMENT LEVEL
}

\author{
DOI: 10.12776/QIP.V18I2.295
}

\author{
JURAJ TEJ, PETER ŽIVČÁK, VIKTÓRIA ALI TAHA, \\ MICHAELA SIRKOVÁ
}

Received 26 February 2014, Revised 8 April 2014, Accepted 8 July 2014

\section{INTRODUCTION}

People constantly face various emergencies, accidents and adverse situations. In order to survive people have to learn to anticipate these situations, prevent their occurrence and to manage them if they occur. The first decade of the 21 st century is characterized by a turbulent and dynamic societal environment, which consists mainly of globalizing economy and integration of states into supranational structures. It raises not only new opportunities and challenges of the knowledge society, but also new threats and risks of economic, social and societal nature crisis phenomena. As indicated Turoff et al. (2013, p. 1655) "given the large number of threats that are possible in the next decade, we need to see far more efforts at planning and foresight for emergencies and exposure of the results of these activities to the public". It is necessary to realize that processes of crisis management are crucial to the protection and safety of the public and state. The secret of correct functioning of crisis management lies in the recognition and realization of the value and contribution of competent persons' and residents' awareness.

The underlying objective of crisis management in public administration is public safety and protection. Basic theoretical, systemic and methodological assumptions of strategic management and planning are applicable to the municipality and the region level as well as to all other governance levels (see also Papcunová and Geciková, 2011). Preparation of the population in Slovakia is not realized (or realized only to a minimal extent) even though from 2006 it declares and determines the Order of Ministry of the Interior of the Slovak Republic No. 524/2006 Coll. 


\section{CRISIS MANAGEMENT IN THE CONTEXT OF SELF- GOVERNMENT}

In growing dynamics of scientific-technological, economic and social development the potential of changes is so vast that every state, region or municipality must constantly deal with analysis of the development trends, especially in the sphere of defence and security of the community (Štancl, 2006). Therefore, the task of crisis management that operates in the public sector (selfgovernment included) is to create legislative, personnel, material and technical conditions for crisis prevention and efficient crisis resolution (Šimák, 2004).

Every society, region, municipality or company is potentially exposed to crisis situations. Survival of the entity depends on the degree of preparedness, quality of crisis management team, efficiency of contingency plans implementation, and monitoring the situation after the crisis event. Timely, decisive and effective action (intervention) may contribute to minimization of the crisis (Tej, et al., 2013). Professional crisis management of the municipality should be stabilizing component of municipality management and should not be changed in the political context i.e. should not be influenced by the results of municipal or other elections. The deficiency at the municipality management level is that many councilors consider themselves mainly as local politicians and they do not accept their managerial role and the resulting responsibility. However, crisis management must be carried out continuously and management of an territory must assume responsibility for crisis preparedness. Figure 1 shows continual approach to crisis management of self-governing entities.

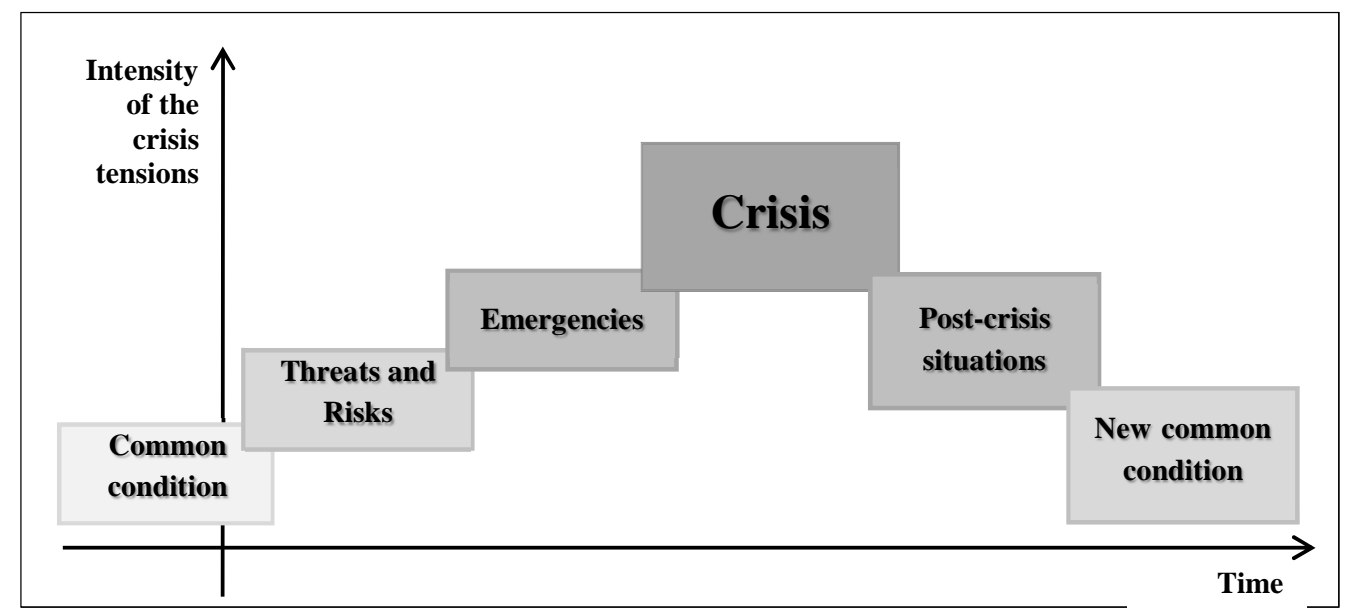

Figure 1 - Continual approach to crisis management in local government Source: elaborated from Antušák (2010)

The risk management process in any public or private entity must be integral part of its culture (Carbone and Tippett, 2004, p. 35). The state administration authorities deal mainly with risk management issues - the possible emergence of 
incidents and emergencies in territorial districts - to the extent and in the manner provided by law. Some systematic steps of the risk management process are implemented in the processing of the comprehensive document, which is called the "Analysis of the area of the territorial district and aspects of potential emergencies" from which the municipalities draw information for activities in the field of crisis management. Municipalities obtain information about the risks of emergencies in the land register (cadaster) through a soft dump from the analysis of the territory in so called Card of Municipality Civil Protection, which serves as a basis for drafting their own public protection plans (Filip et al., 2011). Public protection plans and community response plans are important documents within the crisis management. In relation to the community response plans Becker at al. (2013) note that reduction of risk can occur at different levels: (1) societal level (e.g., structural mitigation for buildings or infrastructure); (2) community level (e.g. development of community response plans); and (3) household level (e.g., assembling emergency plans and kits).

The governance level of municipalities has some peculiarities - mainly due to the predominantly intangible outputs and immediate contact with inhabitants. They can be derived from security situation of examined object. Safety relates generally to existential threats and resulting risks. The basis of safety and security evaluation will not be the assessment of threats to the harmonious development of urban socio-economic space of the municipal district, but the assessment of awareness, knowledge and attitudes of residents and municipal district office staff within the framework of practical performance of crisis.

\subsection{Crisis preparedness and awareness}

One of the areas examined in the survey is the crisis awareness of the city district subjects. In this context it should be noted some terminological inconsistencies notably the use of concepts crisis awareness, risk awareness, or emergency awareness. For the needs of our research we use the term crisis awareness. Regarding this concept it is important to note that crisis awareness is crucial for overall crisis preparedness. The link between these two concepts concisely explains Kapucu (2008) who states that despite the fact "that the literature deals mostly with preparedness it cannot be ignored that awareness needs to come first“. Thus, disaster awareness precedes (is a prerequisite of) disaster preparedness. In this context, the Fielding (2012) argue that being aware is the first step in being prepared, to be able to cope in the face of impending danger.

Emergency preparedness also known as disaster preparedness is a part of emergency management which consists of four stages: (1) reduction, (2) preparedness, (3) response, and (4) recovery (Sutton and Tierneg, 2006 cited in Zhang et al., 2014). Preparedness is defined by Godschalk (1991 cited in Said et al., 2011) as actions taken in advance of an emergency to develop operational capabilities and to facilitate an effective response in the event an emergency occurs. It is important and essential because effective preparedness helps save 
lives, reduce injuries, limit property loss and minimize all sorts of disruptions that disasters cause (Mileti, 1999 cited in Said et al., 2011). Strengthening local preparedness is according Levac et al. (2012) "viewed as an essential element in effective response and recovery". The author defines the (emergency) preparedness as "the knowledge, capabilities and actions of governments, organizations, community groups, and individuals to effectively anticipate, respond to, and recover from, the impacts of likely, imminent or current hazard events or conditions" (Hwacha, 2005 cited in Levac et al., 2012).

At present it is possible to see a shift from the traditional approach to disaster preparedness ("top to bottom" approach where the citizens tend to place the sole responsibility of disaster preparedness and response) to the government to community based disaster preparedness in which disaster preparedness starts at the local level. This approach is essential to foster local resiliency to and responsibility for disaster (Simpson, 2001 cited in Said et al., 2011).

However, public authorities have a key role in ensuring civil protection and in initiating and ensuring population preparedness for emergency situations. Part of emergency preparation could be for example: training programs which according Karanci et al. (2005) "need to give community members a sense of responsibility for mitigation and preparedness". Said et al. (2011) emphasize the need for training enhancing residents' awareness and preparedness (in their case concerning the tsunami). The authors proposed to produce and disseminate information and training materials to the target groups in the local population, training of selected personnel and public lectures (primary activities) as well as interfacing activities for securing smooth running of the education programmes visits to local government agencies and institutions, networking with local groups, and organizing and attending briefing sessions and informal meetings.

According Scolobig et al. (2012) low risk awareness and preparedness of residents may hinder an effective response in case of a natural disaster. That is why this issue is becoming one of the key issues that should be considered for effective emergency planning and management. The authors add that widespread assumption is that "the residents' low risk awareness is among the main causes of an insufficient level of preparedness, which in turn generates inadequate response to disasters". A similar conclusion had been reached also by Turner (1976 cited in Turoff et al., 2013) who points out that in the intervals of time between big similar disasters there is decay of awareness and preparation which is the major cause of poor response to the next similar disaster incident. Previous researches in Turkey showed that although emergency (earthquake) survivors believe in the general possibility of mitigation and preparedness, they attribute responsibility for mitigation and preparedness to external sources, such as the state, municipality, engineers etc. arguing that they themselves have fewer resources for taking such actions than state institutions (Karanci and Aksit, 1999; Karanci and Aksit, 2000 cited in Karanci et al., 2005).

Marinelli (2013) emphasizes that residents and their family members should be made aware of the disaster preparedness plan to help reassure them that there 
exists a formal process in place where a disaster may occur. However, crisis preparedness is a long way but as indicated by McConnell and Drennan (2006) "high levels of crisis preparedness are not "mission impossible", but they are certainly very difficult to achieve. Planners and crisis managers will always struggle against the fact that pre-planning will tend to be low on agendas, while crises themselves are not amenable to advance predictability".

Several researches examined the crisis awareness from different perspectives and in different contexts. For example Fielding (2012) noted that previous research has shown that there is a clear social class gradient in awareness: the lower social classes, the very young people and the very old people (those with the highest financial or social dependency) are least aware of their flood risk (Fielding et al., 2007; Burningham, Fielding, and Thrush, 2008 cited in Fielding, 2012). The study of Burke et al. (2012) that assessed the awareness, perceived risk, and practices regarding disaster preparedness among Latino pointed out, inter alia on several types of preparedness barriers: (1) language difficulties, (2) lack of knowledge, (3) financial difficulties, (4) logistical complications, and (4) apathy (or one's thinking that an event will not affect him) that impede one's ability to be prepared for a disaster.

\section{METHODOLOGY}

The main objective of our study was to determine the level of crisis/emergency awareness and preparedness regarding natural disasters among local residents and municipal district office staff. For the needs of the questionnaire survey there have been earmarked three areas related to crisis management processes in terms of collective protection at the discretion of local self-governments: (1) evacuation, (2) hygiene, (3) communication. Mapping of the situation in these areas in the conditions of the big city divided into municipal districts is considered important in terms of the existence of critical infrastructure (critical infrastructure is a concept that resonates in recent years in the field of academia or central government bodies at both national and international (European) level. Its protection is often associated with terrorism or other socially undesirable phenomena or activities that may result in disruption or destruction of its elements or devices (Hofreiter, 2013; Vidriková and Boc, 2013) as well as expected low level of awareness of residents - triggered by lack of interest in the issue of the civil population protection caused by the change of socio-economic situation in Slovakia.

The main objectives of the survey were to determine: (1) the level of knowledge of municipal district actors (residents and municipal district office staff) of crisis management; (2) the level of awareness among municipal district actors (residents and municipal district office staff) on evacuation issues; (3) the level of awareness among municipal district actors (residents and municipal district office staff) on hygiene issues. 


\subsection{Sample and data collection}

Primary data collection was conducted through a survey (anonymous questionnaire) among residents of the municipal district as well as through interviews with a sample of the municipal district office staff.

The survey participants were residents and representatives of the local Government - Kosice municipal district. Sampling i.e. selection of the respondents - residents was carried out by the snowball sampling technique in March 2013. The aim of the survey was to obtain information about the so-called "crisis literacy" (the concept of "crisis literacy" is used by Antušák (2010) especially in association with the extension of managers' competences. Is a matter for the discretion of each entity/subject (including residents) whether, to what extent and how it accepts these requirements of the time) and statistical evaluation of dependencies between the data obtained.

\subsection{Hypotheses}

Hypotheses formulation was based on some previous researches results, for example the study of Karanci et al. (2005), in which the results of regression analyses (examining the relationship of the variables of the study with disaster cognitions, affect and actual preparedness behaviours) showed that gender, education, being a participant in the training program, anxiety, and locus of control are important variables related to different kinds of disaster-related cognitions.

Among the factors affecting the awareness of the population, we focused on educational attainment and training. Formulation of hypotheses was derived from two premises: the first assumption was that awareness would likely depend on the level of educational attainment; the second assumption was that the crisis awareness of public administration employees (staff of municipal district office) was likely to be higher than crisis awareness of other people - the reason is that state and public administration secures a crucial part of crisis management, the specialized bodies and staff are part of crisis management and civil protection. Therefore it can be assumed greater awareness of state and public administration staff in the field of crisis management and civil protection. Building on these assumptions the following hypotheses were formulated:

1. First hypothesis determines whether educational attainment is related to responses to the survey questions.

$\mathrm{H}_{0}$ : There is no significant relationship between the responses of the respondents and their educational attainment.

$\mathrm{H}_{1}$ : There is a significant relationship between the responses of the respondents and their educational attainment. 
2. Second hypothesis determines whether crisis awareness of public administration employees significantly differ from the crisis awareness of residents (people who are not employed in public administration).

$\mathrm{H}_{0}$ : There are not statistically significant differences in responses between public administration employees and residents (i.e. respondents who are not public administration employees)

$\mathrm{H}_{1}$ : There are statistically significant differences in responses between public administration employees and residents (i.e. respondents who are not public administration employees)

\section{SURVEY RESULTS}

Chi-square test of independence (for categorical variables) was used for determining significant association between variables. One of the conditions of the test is that the expected frequency of each contingency table cell (category) is at least 5. In our survey we interviewed 105 respondents, after correction of 90 questionnaires had been processed by SPSS software.

When assessing general information on crisis management in municipality according to the educational attainment of the respondents - marginal value of chi-square test is probability level $\mathrm{p}=0.05$ (i.e. the results are accepted with a probability of $95 \%)$. On this basis, we conclude that:

a) there is a significant relationship between the respondents' responses to the question about awareness of the implementation of crisis management in the municipality of city district and educational attainment of respondents $(\mathrm{p}=$ 0.028 ;

b) there is no significant relationship between educational attainment of respondents and respondents' responses to the questions:

- regarding the concept of crisis situation $(\mathrm{p}=0.936)$;

- about handling a crisis situation $(\mathrm{p}=0.286)$;

- about the need to respect the instructions (in case of emergency) ( $p=$ 0.936).

Evaluation of the residents' responses on evacuation has brought the following results:

- there is no significant relationship between educational attainment of respondents and respondents' responses to the questions:

- about the evacuation measures $(\mathrm{p}=0.224)$;

- $\quad$ about the emergency evacuation kit $(p=0.865)$;

- about the protective and shelter spaces $(\mathrm{p}=0.265)$;

- about the rules during the evacuation $(\mathrm{p}=0.481)$;

- regarding behaviour in the shelter $(p=0.602)$;

- about spontaneous evacuation $(\mathrm{p}=0.190)$;

- about home (flat) security $(\mathrm{p}=0.532)$. 
Results of respondents' answers to questions relating to threat of the city by water:

- there is no significant relationship between the respondents' responses to the question on threat to water and educational attainment of respondents ( $\mathrm{p}=$ 0.668).

Results of respondents' answers to questions relating the information on hygiene:

- there is no significant relationship between educational attainment of respondents and respondents' responses to the question:

- $\quad$ on hygiene and health care and $(\mathrm{p}=0.777)$;

- about recommended toiletries $(\mathrm{p}=0.364)$.

Results of respondents' answers to question regarding crisis communication:

- there is no significant relationship between educational attainment of respondents and respondents' responses to the question:

- $\quad$ about the sirens sound $(\mathrm{p}=0.431)$;

- about communication during floods $(p=0.738)$;

- $\quad$ about communications during evacuation transport $(\mathrm{p}=0.113)$;

- relating to behaviour after the declaration of an emergency $(\mathrm{p}=0.069)$;

- about emergency (telephone) line ( $\mathrm{p}=0.544)$;

Results of residents' and public administration employees' answers to questions:

a) there are statistically significant differences in responses between public administration employees and respondents who are not public administration employees (residents) to the question:

- concerning the shelters in the residence $(\mathrm{p}=0.059)$;

- concerning the evacuation rules $(p=0.000)$;

- concerning the hygiene and health care $(p=0.002)$;

- concerning the appropriate toiletries $(p=0.029)$;

- concerning the behaviour in the evacuation shelter $(\mathrm{p}=0.042)$;

b) there are not statistically significant differences in responses between public administration employees and respondents who are not public administration employees (residents) to the question:

- relating to emergency telephone lines in case of threat to health, life, property or the environment $(\mathrm{p}=0.801)$.

It can be concluded that there is currently an awareness gap between public administration employees and respondents who are not public administration employees (residents) since in five of the total six questions relating to awareness and knowledge were found statistically significant differences between these two groups.

\section{CONCLUSION}

Crisis awareness does not meet current needs, is insufficient due to the existence of new emerging crises and threats and moreover does not meet the requirements of current legislation. To a similar conclusion about the insufficiency of 
residents' preparedness and awareness was reached also by other authors, for example King (2000) who argue that awareness and preparedness surveys showed that knowledge of both the hazard and appropriate preparation and actions must be improved in order to safeguard life and livelihood. Author also points out that "the experience of people during natural disasters has shown an overwhelming lack of expectation, minimal preparation and confusion over warnings". We assume that the level of crisis awareness of the population in Slovakia is comparable to that in V4 countries and corresponds with the results of researches and studies in other countries. This raises the need to improve training and education of the population in the area of self-protection and mutual assistance in crisis situations.

The results of the survey highlighted the fact that although nowadays the activities related to collective protection of the population are not discussed very much in public (as well as in the school system) the overall public awareness was not the worst. Of course we have to take into account that not practical exercise of surveyed activities was assessed, but their level of opinion was investigated through a questionnaire by using closed questions with scaling. On this basis, we conclude that:

1) The residents of the municipal district regardless of educational attainment are adequately informed, i.e. have sufficient theoretical knowledge of concepts related to crisis management and actions under the collective protection of the population.

2) Public administration employees have better knowledge and information on crisis management issues and activities related to collective protection of the population since their aliquot part fall into of their workload.

3) Residents are adequately/sufficiently informed about telephone lines which should be called in case of threat to life, health, property or the environment.

The head of the crisis management department (in the studied municipal district) accesses comprehensively and systematically to different activities in the field of crisis management. Generally, the most sophisticated part of activity areas on relevant department of the municipality office is the area of the "General information on emergency management" and area of "information about communication" within crisis management.

We propose our recommendations on the basis of analyzing issues of crisis management, the results of the questionnaire survey and interview with representatives of the municipal district (who are ultimately responsible for crisis management issues). We propose to plan the improvement of population awareness of the various activities of the self-government in the field of crisis management, because the population has relatively poor knowledge of the situation in some areas. There are two kinds of proposals: some of them have the character of general proposals (as the findings can to some extent be applied in other cities, districts and municipalities and suggestions) and some are specific to a particular city district. 
1) General suggestions and recommendations:

We propose to improve public awareness through the prepared supportive campaign of crisis management, which will take the form of posters, short articles in local newspapers and on municipal office's website. The content of newsletters should include concise and clear explanations of each the most probable (or most recent) activities of self-government in the field of crisis management and population interoperation (general information, evacuation, spontaneous evacuation, hygiene, fires, communications, tel. number, etc.).

2) Suggestions and recommendations specific for the city district:

a) General information on crisis management:

In a given city district it would be appropriate to raise awareness especially among secondary educated population - respondents. We propose to carry out the information campaign under the auspices of the city district municipality using information vehicle which will pass over individual streets of the city district (for a week), stop at various predetermined places (e. g. near schools in the morning, near parks and shopping centres in the afternoon etc.) and inform residents through prepared presentations. Residents of the city district may be acquainted with the prepared information campaign through promotional materials delivered to mailboxes or published on the website of the municipality office.

b) Field of information on evacuation

Based on the survey results, we believe that it is appropriate that the city district has prepared (printed) materials that will allow residents to access relevant, easily processed and concise information which will help them dispassionately and promptly respond in the case of emergency. For children of the city district we propose to carry out exercises focused on demonstrations of evacuation rules at the accessible place. Given the observed differences in the awareness of residents in terms of their employment (i.e. between those employed and not employed in public administration), the main actors of the exercise will be city district residents with the assistance of municipality staff and various crisis management rescue bodies.

c) Field of information on hygiene

Another suggestion is also promotional. We suggest that the crisis management department of the municipality has created a comprehensive set of information and tangible things for hygiene and health care provided by the municipality during emergencies - the prepared materials should be placed in the showcase at the municipality office to be accessible to all residents of the city district.

d) Field of information on communication

Although residents have information about emergency telephone lines, it is necessary to give them further information concerning the 
communication, e. g. audio signals. This information will be in printed form distributed (by the municipality office) to the places where the residents often reside (e.g. bus stops, information boards, billboards, schools, offices, etc.)

The presented measures can be addressed within the self-government using partnerships as one of the alternative model of political, economic and social decision-making which is based on the assumption that the decision-making process is efficient and effective if it is happening at the active work of those who are hit by the consequences of the decision. In the context of crisis management the future can no longer be seen as a mere continuous continuation of the past. The future period must be seen as a sequence of discontinuities, which have certain regularity. Therefore, it is necessary to organize the future of residents, businesses and other actors and not just react to it.

Lessons learned from the past crises (no matter if it was a crisis of natural, anthropogenic, social, economic or social nature) show that it is better, more efficient and cheaper to take measures to prevent crises than to deal with them when they have occurred.

\section{ACKNOWLEDGEMENT}

The article is a part of the results of the research grant KEGA 017PU-4/2013 Networking of some element of faculty structure.

\section{REFERENCES}

Act No. 414/2002 Coll. on Economic Mobilisation

Act No. 45/2011 Coll. on Critical Infrastructure

Antušák, E., 2010. Zvláštnosti managementu v prvním desetiletí 21. století v kontexte zvládání globalizujících se ekonomických a bezpečnostních krizových jevů. Krízový manažment, 1/2010, pp.8-16. ISSN 1336-0019.

Becker, J. S., Douglas, P., Johnston, D. M. and Ronan, K. R., 2013. Salient Beliefs About Earthquake Hazards and Household Preparedness. Risk Analysis, 33(9), September 2013, pp.1710-1727.

Burke, S., Bethel, J. W. and Foreman Britt, A., 2012. Assessing Disaster Preparedness among Latino Migrant and Seasonal Farmworkers in Eastern North Carolina. International Journal of Environmental Research and Public Health, Vol. 9, 2012, pp.3115-3133.

Carbone, T. and Tippett, D., 2004. Project Risk management Using the Project Risk FMEA. Engineering Management Journal, 16(4).

Fielding, J. L., 2012. Inequalities in exposure and awareness of flood risk in England and Wales. Disasters, 36(3), pp.477-494. 
Filip, S., Šimák, L. and Kováč, M., 2011. Manažment rizika. Bratislava: Sprint dva.

Hofreiter, L., 2013. Teoretické východiská predikcie bezpečnostnej situácie v prostredí kritickej infraštruktúry. Krízový manažment, 2/2013, pp.68-74.

Kapucu, N., 2008. Culture of preparedness: household disaster preparedness. Disaster Prevention and Management. 17(4), 2008. pp.526-535.

Karanci, A. N., Aksit, B. and Dirik, G., 2005. Impact of a community disaster awareness training program in turkey: does it influence hazard-related cognitions and preparedness behaviors. Social behavior and personality, 33(3), pp.243-258.

King, D., 2000. You're on Your Own: Community Vulnerability and the Need for Awareness and Education for Predictable Natural Disasters. Journal of Contingencies and Crisis Management, 8(4), pp.223-228.

Levac, J., Toal-Sullivan, D. and O'Sullivan, T. L., 2012. Household Emergency Preparedness: A Literature Review. Journal of Community Health, 37(3), pp. 725-733.

Marinelli, V., 2013. Prepare for disaster before disaster strikes. Long-Term Living Magazine, March 2013.

McConnell, A. and Drennan, L., 2006. Mission Impossible? Planning and Preparing for Crisis. Journal of Contingencies and Crisis Management, 14(2), pp.59-70.

Order of Ministry of the Interior of the Slovak Republic No. 328/2012 Coll. on Evacuation

Order of Ministry of the Interior of the Slovak Republic No. 524/2006 Coll. amending and supplementing the Order of the Ministry of Interior of the Slovak Republic No. 303/1996 Coll. on the provision of training for civil protection

Papcunová, V. and Geciková, I., 2011. Economic crisis from the perspective of local self-government. In: 14th International Colloquium on Regional Sciences Location. Boretice, Czech Republic, June 22-24, 2011. Praha: CSAV, 2011. pp.175-180. ISBN 978-80-210-5513-1.

Said, A. M., Ahmadun, F., Rodzi Mahmud, A. and Abas, F., 2011. Community preparedness for tsunami disaster: a case study. Disaster Prevention and Management, 20(3), pp.266-280.

Scolobig, A., De Marchi, B. and Borga, M., 2012. The missing link between flood risk awareness and preparedness: findings from case studies in an Alpine Region. Natural Hazards, 63(2), pp.499-520.

Šimák, L., 2004. Krízový manažment vo verejnej správe. Žilina: FŠI ŽU, ISBN 80-88829-13-5

Štancl, L., 2006. Aktuální problémy teorie ekonomiky obrany státu na počatku 21. století. Vojenské rozhledy, 15(3), pp.5-24. 
Tej, J., Bartko, F. and Ali Taha, V., 2013. Manažment rizík a zmien. Prešov: Bookman, ISBN 978-80-89568-73-4

The Act of the National Council of the Slovak Republic No. 261/2002 Coll. on the Prevention of Major Industrial Accidents and on the amendments of some acts

The Act of the National Council of the Slovak Republic No. 387/2002 Coll. on Crisis Management of the State in War and Warfare

The Constitutional Act No. 227/2002 Coll. on the Security of the State in Times of War, Warfare and State of Emergency

Turoff, M., Hiltz, S. R., Bañuls, V. A. and Van Den Eede, G., 2013. Multiple perspectives on planning for emergencies: An introduction to the special issue on planning and foresight for emergency preparedness and management. Technological Forecasting \& Social Change, 80(9), pp.1647-1656.

Vidriková, D. and Boc, K., 2013. Kritická analýza prístupov k problematike ochrany kritickej infraštruktúry v Slovenskej republike. Krízový manažment, 2/2013, pp.44-60. ISSN 1336-0019

Zhang, W., Kong, F. and Jiang, T., 2014. Assessment of emergency preparedness effects of work safety in Xinjiang autonomous region of China based on weighted Rank Sum Ratio. In: Progress in Mine Safety Science and Engineering II - Proceedings of the 2nd International Symposium of Mine Safety Science and Engineering (conference proceedings), 2014. pp.563-565, ISBN 978113800122-0. 


\section{ABOUT THE AUTHORS}

Juraj Tej, Vice dean for Education, University of Prešov in Prešov, Faculty of Management, Department of Management, Slovakia e-mail: juraj.tej@unipo.sk

Peter Živčák, PhD. student, University of Prešov in Prešov, Faculty of Management, Department of Management, Slovakia e-mail: dr.pzivcak@gmail.com

Viktória Ali Taha, Assistant, University of Prešov in Prešov, Faculty of Management, Department of Management, Slovakia e-mail: viktoria.ali-taha@unipo.sk

Michaela Sirková, Assistant, University of Prešov in Prešov, Faculty of Management, Department of Management, Slovakia e-mail: michaela.sirkova@unipo.sk 